\title{
Türkiye’de Yükseköğretim Çalışmaları: Eğilimler ve Öneriler
}

\author{
Hanife Hilal Şenay ${ }^{1 *}$, Mehmet Şengül ${ }^{2}$, Fatma Nevra Seggie ${ }^{3}$ \\ 'Orta Doğu Teknik Üniversitesi, Sosyal Bilimler Enstitüsü, Ankara, Türkiye \\ ${ }^{2}$ Hatay Mustafa Kemal Üniversitesi, Rektörlük, Hatay, Tükiye \\ ${ }^{3}$ Boğaziçi Üniversitesi, Eğitim Fakültesi, Eğitim Bilimleri Bölümü, İstanbul, Türkiye \\ ORCID: H.H. Şenay (0000-0002-5447-6579), M. Şengül (0000-0002-6661-2953), F.N. Seggie (0000-0002-0657-6284)
}

\begin{abstract}
Özet
Yükseköğretim çalışmalarının bir doçentlik bilim alanı olarak kabul edildiği 2015 yılından bu yana, ülkemizde yükseköğretim alanında yapılan çalışmalarda bir artış gözlenmektedir. Bilimsel araștırmaların yanı sıra yükseköğretim odaklı derneklerin ve merkezlerin kurulması, konferans ve çalıştayların düzenlenmesi, ve yükseköğretim çalışmaları alanına yönelik dergilerin çıkarılması, bu alana verilen önemin giderek artmasına ve alandaki sorunların çözümüne yönelik çabaların birer göstergesi olarak görülebilir. Bu açıdan bakıldığında, ülkemizde yükseköğretim alanında gerçekleștirilen tüm bu akademik faaliyet ve araştırmaların çıktılarının değerlendirilmesi, yükseköğretim alanının gelişmesi ve veri-temelli politikaların oluşturulması açısından önem arz etmektedir. Bu araștırmanın amacı, ülkemizde yükseköğretim alanında yapılan çalışmalardaki eğilimleri ortaya çıkarmaktır. Bu hedef doğrultusunda çalışmada, Türkiyédeki yükseköğretim odaklı düzenlenen konferanslardaki sunulan çalıșmalar ile yine bu odakta çıkarılan dergilerdeki makaleler incelenmiștir. Yapılan içerik analizi sonucunda, çalıșmadaki öne çıkan bulgulardan bir tanesi, en çok araștırılan konunun lisans programları ve bu programların değerlendirilmesi ve geliştirilmesine yönelik çalışmalar olduğudur. Bunun dışında, bildirilerde ve makalelerde öne çıkan temalar farklılaşmaktadır. Yapılan çalışmaların araştırma yöntemlerinin benzerlik gösterip ampirik çalışmaların daha ön planda olduğu ve nitel araştırma yaklaşımlarının görece daha sık kullanıldığı bulunmuştur. Çalıșmanın sonuçları ıșığında, yükseköğretimle ilgili ve ilișkili araștırmacılara, konferans düzenleyicilerine, dergi editörlerine, idarecilere ve politika yapıcılarına, politikaların ve araştırmaların birbirini beslemesine ve birbirinden beslenmesine olanak sağlaması yönünde yapıcı öneriler sunulmaktadır.
\end{abstract}

Anahtar kelimeler: Türkiye yükseköğretim sistemi; yükseköğretim çalışmaları alanı; konferans bildirileri; basılı yayınlar

\section{Higher Education Studies in Turkey: Trends and Recommendations}

\begin{abstract}
Since 2015 when higher education studies has been recognized as a scientific field of study for associate professorship, an increase has been observed in studies in higher education in Turkey. In addition to scientific research, establishing higher education-oriented associations and centers, organizing conferences and workshops, and publishing journals for higher education studies can be seen as indicators of efforts to increase the importance given to this field and to solve problems in the field. From this perspective, evaluating the outcomes of all these academic activities and researches in the field of higher education in our country is important for the development of the higher education field and the creation of data-based policies. The purpose of this study is to explore the trends in higher education studies in our country. In line with this objective, articles published in higher education journals and papers that were presented in conferences that specifically focus on higher education were analyzed. As a result of the content analysis, one of the most prominent findings of the study is that the most researched topic was regarding undergraduate programs and the evaluation and the improvement of these programs. Apart from that, the themes that are prominent in articles and conference papers differed. It was also found that empirical studies were more prominent and qualitative research approaches were used more frequently. In the light of these findings, constructive suggestions with regard to policies and academic studies were presented for researchers, conference organizers, journal editors, administrators and policy makers to allow policies and research to feed and be fed from each other.
\end{abstract}

Keywords: Turkish higher education system; higher education studies as a field; conference presentations; published articles

\section{Gíriş}

Yükseköğretimin düşünce olarak ortaya çıkışı, Eflatun'un ve Aristo'nun öncelikli olarak felsefe tartışmalarının yapıldığı, sırasıyla Academia (M.Ö. 400) ve Lyceum (M.Ö.

*Yazışma Adresi / Address for Correspondence:

H. H. Şenay, Email: hsenay@metu.edu.tr

Geliş Tarihi / Received Date: 02.03.2020

Kabul Tarihi / Accepted Date: 13.04.2020

Doi: $10.26701 /$ uad. 697415
387) olarak adlandırılan eğitim kurumlarına dayanmaktadır (Gürüz, 2003). Çin'deki Konfüçyus Akademileri, Hindistan'daki Nalanda Üniversitesi ve medreseler, dünyadaki ilk yükseköğretim kurumları arasında yer almaktadır. Yükseköğretimin kurumsal niteliği itibarı ile üniversite yapısının Batı'da ortaya çıkışı ise 11. ve 12. yüzyllarda Avrupa'da gerçekleşmiştir. Avrupa'da ilk kurulan üniversiteler arasında Bologna (1088), Paris (1119) ve Oxford (1167) Üniversiteleri sıralanabilir (Barnett, 1990).

İlk üniversitelerin kurulduğu geçmiş yüzyıllardan bugü- 
ne dünya çapında düşünüldüğünde, sayıları artarak yirmi binleri bulan yükseköğretim kurumlarında öğrenim gören öğrenci sayısı da katlanarak artmış ve iki yüz milyona ulaşmıştır (UNESCO, 2019). Öğrenci sayılarındaki artış, dünya ölçeğinde oransal olarak düşünüldüğünde, yirminci yüzyılın son çeyreğinde \%10 olan yükseköğretime katılım oranı, yirmibirinci yüzyılın ilk çeyreğinde \%35'e yükselmiştir (UNESCO, 2017). Bu yaşanan artış eğilimi, yükseköğretim kurumlarına yönelik talep ve beklentileri ortaya koymakla beraber yükseköğretim kurumlarını ve sistemlerini de değişip dönüşmeye teşvik etmektedir (Akbulut Yıldırmış \& Seggie, 2018).

Yükseköğretim kurumları, yerel, bölgesel ve ulusal kalkınmada kilit bir rol üstlenmektedir. Çünkü bu kurumlar, ülkelerin sosyo-ekonomik, bilimsel ve kültürel birikimlerinin artırılması ve toplumsal gelişmenin sağlanması için gerekli bilginin üretildiği ve yaygınlaştırıldığı ana arterlerdir. $\mathrm{Bu}$ nedenle, giderek genişleyen ve daha da kritik bir role sahip olan yükseköğretim sistemlerinin geliştirilebilmesi ve güçlendirilebilmesi için sistemleri ve kurumları irdelemeye, hem niceliksel hem de niteliksel olarak gelişimlerini analiz etmeye ve değerlendirmeye ihtiyaç vardır (Akbulut Yıldırmış \& Seggie, 2018). Bu bağlamda dünyanın farklı ülkelerinde olduğu gibi Türkiye'de de yükseköğretim çalışmalarının değerlendirilmesi önem arz etmektedir.

Türkiye yükseköğretimi, 1980 yılında 19 devlet üniversitesine sahip bir sistem iken, yıllar içinde çeşitlenip genişlemiş ve 2019 yılında 129 devlet üniversitesi, 73 vakıf üniversitesi ve 5 vakıf meslek yüksekokulu olmak üzere toplam 207 yükseköğretim kurumunu içinde barındıran büyük bir sisteme dönüşmüştür. Sistemin büyümesi, olanak ve firsatlar ile mücadele ve zorlukları da beraberinde getirmiş, yükseköğretim çalışmalarına olan ihtiyaç giderek daha da fazla ortaya çıkmıştır. 2015 yılında Üniversitelerarası Kurul (ÜAK)'un yükseköğretim çalışmalarını bir doçentlik alanı olarak tanımlaması, Türkiye'de yükseköğretim çalışmalarının bir bilim alanı olarak gelişmesi adına önemli bir adım olmuştur. Bu tarihten itibaren, Türkiye'de "yükseköğretim çalışmaları” alanındaki akademik faaliyetlerin hız kazandığını söylemek mümkündür. Yapılan akademik faaliyetlerin, özellikle araştırma çıtılarının veritabanı oluşturarak politikalara kanıt oluşturabilme, yön verebilme ve politikaları geliştirerek güçlendirebilme potansiyeli olduğu göz önünde bulundurulduğunda, Türkiye'de yeni doğan yükseköğretim çalışmaları alanında yapılan çalışmaların irdelenmesi önemlidir. Bu bağlamda, bu araştırmanın amacı, yükseköğretim alanında yapılan çalışmalardaki eğilimleri ortaya çıkarmaktır. Bu kapsamda, bu araştırmanın soruları aşağıdaki gibidir:

\section{Yükseköğretim alanında yapılan çalışmalarda öne çıkan temalar nelerdir?}

2. Yükseköğretim alanında yapılan çalışmalarda hangi araştırma desen ve yöntemleri kullanılmıştır?
Bu araştırma, alana özgü çalışmalar yapan bilim insanlarına, yükseköğretim çalışmalarına ilişkin faaliyetleri düzenleyen yöneticilere (dergi editörleri, konferans düzenleyicileri ve dernek yöneticileri gibi), ve politika yapıcılarına alanın görünür bir kimlik kazanması sonrası yapılan bilimsel faaliyetlerin resmini sunarak geleceğe yönelik Türkiye yükseköğretim ekosisteminin gelişimine katkıda bulunmayı hedeflemektedir.

\section{ALANYAZIN TARAMASI}

\subsection{Bir alan olarak yükseköğretim çalışmaları}

Bu kısımda, alan kavramının tanımı yapılmakta olup, bir alanın gelişimi için nelerin olması gerektiği ve Türkiye'de yükseköğretim çalışmaları alanının gelişimine katkı veren olaylar ele alınmaktadır. Yükseköğretim çalışmalarının "alan" veya "disiplin" olup olmadığı yönünde görüş ayrılıkları olsa da alanda önemli söz sahibi olan Dressel ve Mayhew (1974, akt. Wright, 2007), yükseköğretim çalışmalarının "alan” olarak tanımlanması gerektiğini savunmuşlardır. Bunun yanı sıra, Wright (2007) bir alanın gelişiminde rol oynayan bazı özelliklerin var olduğunu belirtmişlerdir. Bu özellikler, alana özgü parametrelerin belirlendiği çalışmaların, kendine özgü terminolojinin, uzlaşı sağlanılan ve çoğunlukla kullanılan yöntem ve tekniklerin olmasını, araştırma deneyimi açısından bilgi birikiminin oluşmasını, ve teorik soruların cevaplandırılması ile yeni teorilerin geliştirilmesini kapsamaktadır. $\mathrm{Bu}$ özelliklere ek olarak, Yükseköğretim Çalışmalarının diğer disiplinlerden etkilenmesi ve beslenmesi göz önünde bulundurulduğunda, alan olarak tanımlanmasının daha uygun olacağı düşünülmüştür (Dressel \& Mayhew, 1974; akt. Wright, 2007). Benzer şekilde, Fulton (1992) da yükseköğretim çalışmalarında ciddi bir gelişme olsa da henüz tam anlamıyla bir disiplin olmadığını iddia etmektedir. Ülkemizde de yaygın bir şekilde görüldüğü üzere, yükseköğretimin alan olarak çalışılmasından ziyade eğitim çalışmalarında bağlam veya etken olarak ele alınması alanın gelişimini yavaşlatmıştır (Brennan \& Teichler, 2008). Tartışmaya katılan bir başka bilim insanı Altbach (2014) ise, yükseköğretim çalışmalarını sosyal bilimlerden beslenen disiplinlerarası akademik bir alan olarak benimsemiştir. Akbulut Yıldırmış ve Seggie (2018), yükseköğretim çalışmaları alanının gelişimini ele aldıkları derleme çalışmalarında yükseköğretim çalışmaları alanında coğrafi genişleme yaşandığı ve bu alanın büyüme eğiliminde olduğu belirtmektedirler.

Yukarıdaki çalışmalar göz önüne alındığında, yükseköğretim çalışmalarının halen gelişimini tamamlamadığı, gerek sosyal bilimler gerekse eğitim bilimleri çalışmalarında bağlamsal veya tamamlayıcı alan olarak dâhil edilmesinin alanın gelişim sürecini etkilediği ve bu alanın birçok disiplinden beslendiği görülmektedir.

\subsection{Türk yükseköğretim sistemi}

Türk yükseköğretim sisteminin kanuni temeli, 6 Kasım 1981 yılında yapılan düzenlemeler kapsamında yürür- 
lüğe giren 2547 sayılı Yükseköğretim Kanunu'na dayanmaktadır. Bu kanunla birlikte, 1982 Anayasasının 130. ve 131. maddeleri uyarınca, ülkemizde yükseköğretim sistemi ve yükseköğretim kurumları Yükseköğretim Kurulu (YÖK)'nun sorumluluğuna bağlanmıştır (Akbulut Yıldırmış \& Seggie, 2018). Mevcut haliyle Türk yükseköğretim sisteminde, lisans, yüksek lisans ve doktorayı kapsayan üç seviyeli sisteme ek olarak kısa dönem olarak da adlandırılan önlisans eğitimi de verilmektedir (Erdoğan, 2010).

Ayrıca, 207 yükseköğretim kurumunun bulunduğu sistem içerisinde yaklaşık 3.7 milyonu kadın ve 4.07 milyonu erkek olmak üzere, 7.7 milyon öğrenci eğitim görmektedir. Bu sayıyı detaylandırırsak, 2.8 milyon öğrenci önlisans, 4.4 milyon lisans, 400 bin yüksek lisans ve 97 bin öğrenci ise doktora eğitimi almaktadır. Kadın öğrencilerin erkeklere oranına bakıldığında, Türk yükseköğretim sistemi Avrupa'daki çoğu gelişmiş ülkenin önünde yer almakta olup yükseköğretimde fırsat eşitliği konusunda örnek teşkil etmektedir. Akademisyen sayısı göz önüne alındığında ise, 75 bin kadın akademisyen ve 92 bin erkek akademisyen üniversitelerde görev yapmaktadır. Unvanlara göre dağılımda ise, 27 bin profesör, 16 bin doçent, 40 bin doktor öğretim üyesi, 37 bin öğretim görevlisi ve 49 bin araştırma görevlisi bulunmaktadır. Uluslararasılaşma bağlamında 181 ülkeden 155 bin uluslararası öğrenci Türk yükseköğretim sisteminde eğitim almaktadır (https://istatistik.yok.gov.tr/).

\subsection{Türkiye'de yükseköğretim sistemine ilişkin makro düzeyde stratejiler ve gelişmeler}

Gelişmelerin ve reformların sıklıkla yer aldığı Türk yükseköğretim sistemi içerisinde, özellikle sistemin genişlemesi açısından 1992 ve 2006 yılları, iki önemli kırılma noktası olarak kabul edilmektedir (Günay \& Günay, 2017). Birincisi, 1992 yılında 24 üniversitesinin aynı anda kurulması ve üniversite sayısının 29'dan 53'e çıkması; ikincisi de 2006 yılında "her ile bir üniversite" projesi ile üniversite sayısının 100'den daha yukarı sayılara ulaşmasıdır.

Sistemin genişlemesi açısından yukarıda belirtilen iki kırılma noktasının yanı sıra bu çalışmada, Türk yükseköğretim sisteminin alan olarak gelişmesine dair yaşanan makro boyuttaki reformlar üç temel başlıkta ele alınmaktadır. İlk olarak, 2001 yılında Türk yükseköğretim sisteminin Bologna Süreci'ne dâhil olması, yükseköğretim sistemimiz açısından bir dönüm noktası olmasından dolayı 2001 yılına kadar yaşanan görece başlıca gelişmeler ilk ana başlıkta sıralanmıştır. Burada, yükseköğretim çalışmalarının bir bilim alanı olarak ele alınmasından önce ağırlıklı olarak yükseköğretime ilişkin politikaların ağırlıklı çalışmalar olduğunu da söylemek yerinde olacaktır. Sonrasında ise, Üniversitelerarası Kurul tarafından yükseköğretim çalışmaları alanın bir bilim alanı kabul edilmesine kadar olan zaman dilimi, yani 2001-2015 yıllarında yaşanan gelişmeler ikinci ana başlıkta ve son olarak 2015 yılı sonrasında yaşanan gelişmeler, üçüncü ana başlıkta toplanmıştır. Çalışmanın odak noktası, özellikle bir bilim alanı olarak yükseköğretim çalışmaları olduğundan aşağıda bu alanın gelișmesine katkıda bulunan çalışmalara yer verilmeye çalışılmıştır.

\subsubsection{1 öncesi gelişmeler}

Yukarıda bahsi geçen 2547 sayılı kanuna bağlı olarak faaliyet gösteren 19 devlet üniversitesi, devletleștirilen özel yüksekokullar ile Milli Eğitim Bakanlığı'na bağlı enstitüler ve yüksekokullar, 1981 yılında faaliyet göstermekteydi (Tekeli, 2010). Daha sonra, 1984 yılından itibaren vakıf üniversitelerinin sisteme dâhil olması dolayısıyla sistemde bir çeşitlenme hâsıl olmuştur. Giderek çeşitlenen, büyüyen ve gelişen bu sistem farklı dönemlerde farklı sorunlarla karşı karşıya kalmıştır.

\subsubsection{1-2015 arası gelișmeler}

2001 yılında Türkiye Bologna Süreci'ne dâhil olmasıyla, Türk yükseköğretim sistemi farklı bir boyut kazanmıştır (Erdem, 2013). Hareketlilik konusunun giderek büyük bir önem kazanmasının yanı sıra yükseköğretimde kalite ve yeterlilikler gibi boyutlar, Türk yükseköğretim sistemi içerisinde tartışılmaya ve politika bağlamında ilgili kurumlarda çalışılmaya başlanmıştır. Bu kapsamda, üniversitelerde Bologna Eşgüdüm Komisyonları kurulmuş olup YÖK'e danışmanlık yapması adına Bologna Uzmanları seçilmiştir.

Bununla birlikte, Türkiye'de çok sayıda yükseköğretim kurumunun açılması, nitelikli öğretim üyesi ihtiyacını ortaya çıkarmıştır. Bu sebeple, yüksek lisans, doktora ve doktora sonrası eğitim programlarının genişletilmesi ihtiyacı doğmuştur. Bu ihtiyaçlar ve bu doğrultuda atılması gereken adımlar, YÖK tarafından hazırlanmış raporlarda belirtilmektedir (YÖK, 2006). Dolayısıyla, yükseköğretim için nitelikli ve yeterli sayıda öğretim üyelerine ihtiyaç duyulması ve araştırma görevlilerinin yurt dişına gönderilmesinin yüksek maliyetli olması nedeniyle, nitelikli öğretim üyesi yetiştirmek amacıyla, 2002 senesinde ilk defa Orta Doğu Teknik Üniversitesi'nde Öğretim Üyesi Yetiştirme Programı hayata geçirilmiştir (Karakütük \& Özdemir, 2011).

Ayrıca, Yükseköğretim Akademik Değerlendirme ve Kalite Geliştirme Komisyonu (YÖDEK)'nun 2005 yılında kurulmasıyla kalite güvencesi çalışmaları önem kazanmıştır. $\mathrm{Bu}$ çalışmalar neticesinde, Avrupa Komisyonu tarafından 2009 yılında başlatılan ve 2013 yılında sonlandırılan Avrupa Kredi Transfer Sistemi (AKTS) ve Diploma Eki etiketlerine Türk üniversitelerinden büyük bir rağbet sağlanmış ve 2013 yılı itibariyle, AKTS Etiketini 31 ve Diploma Eki Etiketini ise 57 Türk yükseköğretim kurumu almaya hak kazanmıştır (https://eacea.ec.europa.eu). 2011 yılında ise, 6111 sayılı kanun ile birlikte AKTS zorunlu hale getirilmiştir. Böylelikle, Türk yükseköğretim sisteminde hareketlilik ve uluslararasılaşma boyutları önündeki kredi sorunu nispeten azaltılmıştır (Gündoğdu. Çelik, Yanar, Yolcu \& Ceylan, 2016). 


\subsubsection{5 sonrası gelişmeler}

Yükseköğretim çalışmaları alanının ÜAK tarafından bilim alanı olarak kabul edilmesi, bu çalışmanın ana ilham kaynağı kabul edilebilir. Gerek politika uygulayıcı kurum veya kişilerin çalışmaları, gerekse akademi camiasında daha uzun bir tarihe sahip olmasına rağmen bilim alanı olarak belirlenmesi, yükseköğretim çalışmaları alanındaki bilimsel verilerin ve ürünlerin artmasına ivme kazandırmıştır.

2015 yılından itibaren yükseköğretimden sorumlu ana kurum olan YÖK tarafından oldukça kritik atılımlar gerçekleştirilmiştir. En önemlilerinden biri, şüphesiz YÖK’ten bağımsız işlev görecek Yükseköğretim Kalite Kurulu'nun oluşturulmasıdır. Her ne kadar bu kurulun ilk kurulması YÖK içerisinde bir birim gibi olsa da 2017 yılında bu kurul tamamen bağımsız bir kurul halini almıştır. Bu Kurulun ana görevi, yükseköğretim kurumlarında yürütülecek kalite güvencesi çalışmalarının teşvik edilmesi ve kalite güvencesi kuruluşlarının sertifikasyon süreçlerinin de daha sistemli değerlendirilmesidir (Kayıkcı, 2018).

Bir diğer kayda değer atılım, Araştırma Odaklı Üniversiteler ile Bölgesel Kalkınma Odaklı Üniversitelerin belirlenmesidir. 2017 yılında YÖK tarafından başlatılan çalışmalar neticesinde, 10 Araştırma Odaklı Üniversite ve 5 Bölgesel Kalkınma Odaklı Üniversite belirlenmiştir. Misyon Farklılaşması ve İhtisaslaşma Projesi kapsamında geliştirilen bu model ile araştırma kapasitesi, araştırma kalitesi ve etkileşim ve işbirliği alanlarında üniversitelerin verimliliğinin artırılması planlanmaktadır (Saraç, 2019).

Yükseköğretim Alanı kapsamında sadece ülkemizde değil, aynı zamanda Avrupa'da birçok ülkede de Meslek Yüksekokullarının niteliği sorgulanmaktadır (Winch \& Clarke, 2003). Bu noktada, YÖK tarafından üniversitelerde Meslek Yüksekokullarında görev yapan temsilcilerin yanı sıra ilgili paydaş kurumları kapsayacak şekilde Meslek Yüksekokulları Koordinasyon Kurulu oluşturulmuştur. Böylelikle, meslek yüksekokullarının kalitesinin artırılması ve ara eleman iş gücünün niteliğinin iyileştirilmesi adına çeşitli toplantılar ve paneller gerçekleştirilerek buralarda yaşanan sorunlar tespit edilmiş ve çözüm önerileri geliştirilmeye çalışılmıştır.

2011 yılında Hareketlilik boyutunda Erasmus+ benzeri olarak başlatılan Mevlana Projesi, 2015 yılında Proje Tabanlı Mevlana Projesi olarak revize edilerek üniversitelerden proje başvurusu alınmıştır. Mevlana Projesinin, bilim ve teknoloji bakımından bölge ülkelerinin cazibe merkezi olmasına katkı sağladığı düşünülmektedir (Günay, 2011).

Avrupa Üniversiteler Birliği çalışmalarında büyük bir yere sahip olan doktora eğitimi de, Türk yükseköğretim sisteminde yaşanan gelişmeler arasında kendine yer bulmuştur. Doktora çalışmalarının, hem akademiye bilim insanı yetiştirmesi hem de sanayide ve sektörde nitelikli doktora mezunları istihdam edebilmesi amacıyla Yükseköğretim Kurulu tarafindan 100/2000 Doktora Bursu başlatılmış ve
Proje Tabanlı Mevlana Projesi'nde olduğu gibi üniversitelerden başvuru talep edilmiş ve başvuruların değerlendirilmesi farklı disiplinlerden oluşturulan komisyonlar tarafından yapılmıştır. 1416 sayılı kanun gereğince, yurtdışı görevlendirmeleri de 2019 yılı itibariyle farklı alanları da kapsayacak şekilde revize edilmiştir. Ayrıca, YÖK tarafından oluşturulan Uluslararasılaşma Strateji Raporu ile Türkiye yükseköğretiminin uluslararası alanda bir cazibe merkezi haline getirilmesi amaçlanmakta ve bu amaçla stratejik hedefler belirlenmiştir.

Yukarıda belirtilen gelişmelere ek olarak, 9 üniversitede (Ankara Sosyal Bilimler, Bülent Ecevit, Çanakkale, İstanbul Aydın, İstanbul Bilgi, İstanbul Şehir, Marmara, Maltepe ve Sakarya Üniversiteleri) yükseköğretim merkezleri kurulmuş olup bu merkezlerde yükseköğretim alanının gelişmesine yönelik çalışmalar yürütülmektedir. Ayrıca, yükseköğretim çalışmalarına özgü çıkan dergi sayısı da üçe çıkmıştır (Yükseköğretim-http://www.yuksekogretim.org/, Yükseköğretim ve Bilim -http://higheredu-sci. beun.edu.tr/ ile Üniversite Araştırmaları-https://dergipark.org.tr/tr/pub/uad dergileri).

“Akademik Teşvik Ödeneği Yönetmeliği”nin 18 Aralık 2015 tarihli ve 29566 sayılı Resmi Gazete'de yayımlanarak yürürlüğe girmesiyle akademisyenler daha fazla yayın yapmaya teşvik edilmeye çalışılmıştır. Bu akademik teşvik sistemi ile birlikte gerek sözlü gerekse yazılı çalışmaların sayısının bir hayli artış gösterdiği gözlenmektedir (Turan, Dil \& Sağır, 2019). Okumuş ve Yurdakul (2017), bu teşvik sistemi sonrası yapılan çalışmalarda nitelik ve etik sorunların olduğunun altını çizmektedirler.

Yukarıda belirtilen gelişmelere ek olarak, yükseköğretim çalışmaları alanında dört üniversitede sadece yüksek lisans düzeyinde program bulunmaktadır. Ülkemizde yapılan tezler incelendiğinde ise yükseköğretim çalışmalarının sayısı, 139'u Doktora düzeyinde ve 356'sı Yüksek Lisans düzeyinde olmak üzere 495'tir.

YÖK tarafından önemli atılımlardan biri de 8 üniversite (Ağrı İbrahim Çeçen, Bayburt, Bingöl, Iğdır, Munzur, Muş Alparslan, Siirt ve Şırnak Üniversiteleri) pilot üniversite olarak belirlenerek dijitalleşme projesidir. Bu üniversitelerde görev yapan 3 binin üzerinde akademisyen (138 Profesör, 152 Doçent, 1089 Doktor Öğretim Üyesi, 864 Öğretim Görevlisi ve 850 Araștırma Görevlisi), dijital ortamda "Dijital Çağda Yükseköğretimde Öğrenme ve Öğretme” dersini almıştır. Ayrıca, bu üniversitelerde eğitim gören 40 bin civarında ögrrenci de, dijital okur-yazarlık farkındalıklarının artırılması adına "Dijital Okur-Yazarlık" dersini almışlardır. Projenin 2. etabı kapsamında 8 yeni üniversitenin (Ardahan, Artvin Çoruh, Batman, Bitlis Eren, Gümüşhane, Hakkâri, Kilis 7 Aralık ve Osmaniye Korkut Ata üniversiteleri) projeye dâhil edilmesine ilişkin protokol imzalandığı “Türkiye'nin Firsat Penceresi: Türk Yükseköğretimi” adlı toplantıda bildirilmiştir (https:// www.yok.gov.tr). 
Uluslararasılaşma kapsamında, 30 Haziran 2017 tarihinde 2018-2022 yıllarını kapsayan Yükseköğretimde Uluslararasılaşma Strateji Belgesi YÖK tarafından hazırlanmış olup uluslararasılaşma stratejileri ve hedefleri belirlenmiștir. Bu doğrultuda, Yükseköğretim Kurumları Sınavı (YKS) kılavuzunda yer alan programların kontenjanlarının "en fazla \%50'sine kadar yabancı uyruklu öğrenci kabul etme sınırlaması" ortadan kaldırılmıștır.

\subsection{Yükseköğretim alanında politikalar ile yükseköğretim çalışmalarının birbirini beslemesi}

Yükseköğretim Çalışmaları alanı kapsamında yapılan makale ve bildiri gibi çalışmalarla yükseköğretimden doğrudan veya dolaylı sorumlu olan kurumların arasındaki uyuma bakacak olursak farklı mecralarda farklı görüşler ortaya çıkmaktadır. Bir taraftan, bu iki yapının birbirinden bağımsız çalışmasının önemi, diğer bir ifadeyle akademik camianın belli konuları çalışması hususunda sınırlandırılmaması ve araştırma ve politikaların illa ki bir uyum göstermesi gerekmediği savunulmuştur (Tierney \& Lechuga, 2005; Ferlie. Musselin \& Andresani, 2008). Diğer taraftan ise, akademik çalışmaların, alınan kararları ele almasının, ve benzer şekilde, ilgili sorumlu kurumların da sahada yapılan çalışmaları dikkate alarak veri-temelli politikalar üretmesinin önemli olduğu vurgulanmıştır (Erdoğan, 2014). Bilginin hem çok çeşitlenip fazlalaştığ 1 hem de erişilebilir kılındığı 21. yüzyıl dünyasında, güvenilir ve temsili veri (Usta, 2019) kültürünün oluşması, veriler doğrultusunda ihtiyaçların belirlenip, hedeflerin tespit edilmesi, ve veriye dayalı politikaların oluşturulması sistemlerin sürdürülebilir gelişimi bakımından gerekli olarak değerlendirilmektedir (Turan, 2019). Dolayısıyla, yükseköğretim çalışmaları kapsamında düşünüldüğünde, politikaların ve araştırmaların birbirini beslemesi ve birbirinden beslenmesi kavramları alana daha fazla katkı sunacaktır (Choi vd., 2005) demek mümkündür.

$\mathrm{Bu}$ bağlamda, akademi ile politika belirleyiciler arasında illa bir uyum olması değil de, tutarlılık ve yakınlık dâhilinde birbirinden beslenmesi alanı daha ileriye taşıyacaktır. Alanın gelişmesi de, üniversitelerin iyileşmesini ve gelişmesini olumlu bir biçimde etkileyecektir.

\section{YÖNTEM}

\subsection{Araştırma modeli}

Bu çalışmanın amacı, ülkemizde yükseköğretim alanında yapılan çalışmalara dair bir mevcut durum tespiti yapmaktır. Bu hedef doğrultusunda, nitel araştırma deseninde tasarlanan bu çalışmada, derleme yöntemi ile alanda yapılan çalışmalar bir araya getirilerek incelenmiştir.

\subsection{Veri toplama araçları}

Bu çalışmada, 2 temel veri seti kullanılmaktadır: yükseköğretim alanı dâhilinde konferanslarda sunulan bildiriler ve basılı yayınlardır. Dolayısıyla, bu çalışmada, Lewis (2003)'in doğal olarak meydana gelmiş veri (naturally occurring data) olarak adlandırdığı veriler kullanılarak, do- küman incelemesi yoluyla analiz edilmiştir.

Yin (2011), doküman incelemesi çalışmalarında konu ne olursa olsun araştırmanın kapsamına girecek çok fazla doküman olacağı ve bu dokümanların toplanmasının ve incelenmesinin çok çaba ve zaman gerektireceğinin altını çizmiştir. Bu nedenle, Yin (2011), bu çalışmalarda verimliliğin sağlanabilmesi için çalışmanın ve toplanacak dokümanların (belge, obje, fotoğraf vb.) kapsamının dikkate alınması gerektiğini belirtmiştir. Ayrıca, tek bir örneklemin yeterli olup olmaması veya var olan tüm dokümanların toplanması hususunun etraflıca değerlendirilmesini önermiştir. Buradan yola çıkarak, bu çalışmanın kapsamını oluşturan yükseköğretim alanı üzerine basılı yayın ve bildirilerin sayısının oldukça fazla olduğu söylenebilir. Bu nedenle çalışmanın geçerliliği ve uygulanabilirliği açısından veri toplama adımında bazı kriterler belirlenmiştir.

Veri toplamada göz önünde bulundurulan kriterlerden ilki, toplanacak olan bildiri ve basılı yayınların tarihidir. $\mathrm{Bu}$ çalışmanın genel amacı, yukarıda da belirtildiği üzere, Türkiye'deki yükseköğretim çalışmaları hakkında genel bir çerçeve oluşturmaktır. Fakat bunun yanında bu çalışmada, yükseköğretimin bir alan olarak genişlemesine katkı yapmak da hedeflenmektedir. Bu sebeple, bildiri ve yayınlar derlenirken yükseköğretimin resmi bir doçentlik alanı olarak kabul edildiği 2015 yılı referans alınmıştır. Bu sayede, hem yükseköğretim alanının gelişimi gözlemlenebilecek, hem de 2015-2018 yılları arasında yapılan çalışmalar analiz edilerek güncel tartışmalara katkıda bulunulacaktır. Buna ek olarak, çalışmanın analizleri yapılırken 2019 yılı tamamlanmadığı için bu yıldaki çalışmalar kapsam dışında bırakılmıştır.

Çalışmaların derlenmesindeki ikinci kriter ise toplanacak çalışmaların süreklilik arz etmesidir. Gündem oluşturabilmesi, alanın gelişimini destekleyebilmesi ve yükseköğretim politikalarına yön verebilmesi için basılı yayın ya da bildirilerin periyodik olarak ya da belirli aralıklarla tekrarlanıyor olması şarttır. Bu sebeple, yükseköğretim alanı üzerine yapılmış olan, fakat süreklilik gözetmeksizin farklı zamanlarda gerçekleşmiş olan kongre, fuar ve seminerler ile alanda basılmış kitap ve süresiz dergi vb. yayınlar, bu çalışmaya dâhil edilmemiştir.

Bunun yanında, yükseköğretimin bir alan olarak gelişebilmesi için, yapılan çalışmaların güçlü bir bilimsel altyapıya sahip olması gerektiği düşünülmektedir. Bu sebeple bu çalışmada sadece hakemli ve bir danışma/editör kurulu inceleme sürecinden geçmiş yayınlar dâhil edilmiş, ve süreklilik arz etse bile bir hakem sürecinden geçmemiş çalışmalar kapsam dışında tutulmuştur.

Son olarak, çalışmalar derlenirken, yayın ve bildirilerin yükseköğretim odaklı bir mecrada yayınlanmış ya da sunulmuş olmasına dikkat edilmiştir. Türkiye'de hakemli ve süreli birçok dergi ve konferans bulunmaktadır ve bu konferanslarda ve basılı yayınlarda yükseköğretim üzerine çalışmaların da olduğu bilinmektedir. Fakat, tüm yayın 
ve konferanslardan genel eğitim odağı dışında asıl olarak yükseköğretim alanına katkı yapma gayesi güden yayın ve konferanslar bu çalışmaya dâhil edilmiştir.

Tüm bu belirtilen kriterler göz önünde bulundurularak, alanda, 3 akademik dergi ve 2 farklı konferansta sunulan bildiriler veri setine dâhil edilmek üzere belirlenmiştir. Bunlar, Yükseköğretim Çalışmaları Derneği (YÖÇAD) tarafından düzenlenen Uluslararası Yükseköğretim Çalıșmaları Konferansı (IHEC), Sakarya Üniversitesi tarafından düzenlenen Uluslararası Yükseköğretimde Kalite Konferansı (ICQH), Yükseköğretim Strateji ve Araştırma Derneği tarafından basılan Yükseköğretim Dergisi, Zonguldak Bülent Ecevit Üniversitesi tarafından basılan Yükseköğretim ve Bilim Dergisi ve Üniversite Araştırmaları Dergisi'dir. Çalışmada belirtilen dergi ve konferansların web siteleri üzerinden 2015 ve 2018 yılları arasında basılan dergilerin cilt ve sayıları, konferansların bildiri özeti kitapçıkları ve tam metin bildiri kitapları analiz edilmek üzere derlenmiştir.

\subsection{Verilerin analizi}

Çalışmada derlenen makale ve bildirilerin analizi için içerik analizi kullanılmıştır. Nitel araştırmalarda içerik analizi, çeşitli doküman, metin ve sözlü verileri inceleyerek belirli kelime, tema ve kavramları ortaya çıkarmak için kullanılır (Kızıltepe, 2017). Bu tanımdan hareketle, bu çalışmada da makale ve bildiri özet veya tam metinleri incelenmiş ve çalışmanın ana teması (konusu), araştırma deseni (ampirik ya da kavramsal), araştırma yöntemi (nitel, nicel, karma vb.), veri toplama araçları (mülakat, doküman analizi, literatür taraması vb.), verilerin analizi (betimsel, çıkarımsal ve içerik analizi), örneklem (öğrenci, akademisyen, yönetici vb.) ve örneklem büyüklüğü (1-50 arası, 50-100 arası katılımcı vb.) olmak üzere 6 ana başlık altında temalandırılarak gruplandırılmıştır. Buna ek olarak, içerik analizinin güvenirliği için tema ve gruplandırmalar yapıldıktan sonra alanda uzman bir akademisyenden görüş alınmıştır.

Yapılan çalışmalara dair temalar belirlenirken hem anahtar kelimelerden hem de çalışmanın metninden yola çıkarak öncelikle her çalışmaya en dar kapsamda bir tema belirlenmiştir. Sonrasında ise, birbirine yakın temalar bir ana tema altında birleştirilmiștir. Örneğin, yükseköğretimde bilgi teknolojileri üzerine olan bir çalışma için verilen ilk tema "bilgi teknolojileri” olmuştur. Bu kodlamalar yapıldıktan sonra, bu tema "bilişim sistemleri" olarak temalandırılan farklı bir çalışma ile "dijitalleşme ve eğitim teknolojileri” ana teması altında birleştirilmiştir.

\section{BULGULAR}

Çalışmanın bulguları, bildirilere ilişkin bulgular ve basılı yayınlara ilişkin bulgular olmak üzere iki alt grupta toplanmaktadır.

\subsection{Bildirilere ilişkin bulgular}

Bildiri özetleri ve tam bildiri özeti kitapları incelendiğinde bu konferanslarda toplamda 1.118 bildiri sunulduğu bulunmuştur. Bu bildiriler arasından 153 tanesi doğrudan yükseköğretim alanıyla ilișkili olmadığı için kapsam dıșına alınmıştır. Bu sebeple, analizlerde 965 çalışmaya ilişkin sonuçlar sunulmuştur.

Şekil 1'de görüldüğü üzere, 2015-2018 yılları arasında en çok bildiri 2016 ve 2017 yıllarında gerçekleşen ICQH konferanslarında sunulmuștur. Bunun yanında, IHEC konferanslarında sunulan bildirilerin sayısı yıllar içerisinde benzerlik gösterirken, ICQH konferanslarında sunulan bildiri sayısında azalma yaşanmıştır.

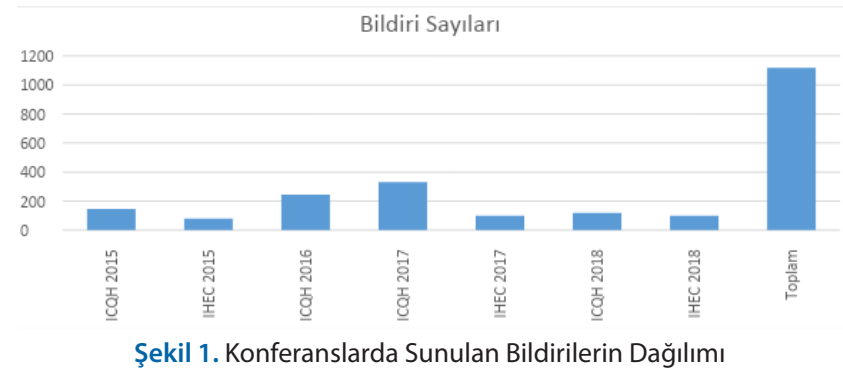

\subsubsection{Bildirilere iliskin temalar}

Konferanslarda sunulan bildirilerin ilk temalandırma çalışmasında toplamda 74 tema oluşturulmuştur. Sonrasında, bu temalar ana temalar altında birleştirildiğinde toplamda 15 tema ortaya çıkmıştır. Şekil 2'de de görüldüğü üzere, bu temalar doğrultusunda konferanstaki bildiriler incelendiğinde konferanslarda sunulan bildirilerin büyük bir kısmının yükseköğretim alanının genelini kapsayacak çalıșmalardan çok fakültelerdeki belirli lisans programlarındaki mevcut durumun anlaşılması ve iyileștirilmesi adına yapılan çalıșmaları içeren "fakülteler" teması oluşturmaktadır.

Lisans programlarına yönelik çalışmalardan sonra en sık çalışılan konular ise sırasıyla kalite, dijitalleşme ve eğitim teknolojileri, eğitim (örgüt) yönetimi ve eğitim programları, öğretim teknikleri ve ölçme değerlendirme olmuştur. Konferanslarda en az çalışılan konuların ise üniversiteye geçiş ve yükseköğretim ekonomisi ve finansmanı olduğu bulunmuştur.

Konferanslarda sunulan bildiriler arasında en çok çalışılan tema olan lisans programları kendi içerisinde fakülteler bazında incelendiğinde ise çalışmaların çok büyük bir çoğunluğunun sağlık eğitimi ve öğretmen eğitimi üzerine olduğu bulunmuştur. Bu çalışmaları, mimarlık ve mühendislik ve de mesleki eğitim temaları takip etmiştir. Konferanslarda en az çalışılan temaların ise güzel sanatlar ve fen-edebiyat (kimya, tarih, sosyoloji vb.) programlarına yönelik olduğu ortaya çıkarılmıştır. Mesleki eğitim ve yüksekokullar ile mühendislik ve mimarlık programlarının dağılımı da Şekil 3'te verilmektedir.

\subsubsection{Bildirilere ilişkin çalışma yöntemleri Araștırma Deseni ve Yöntemi:}

Konferanslarda sunulan bildirilerin araştırma desenlerine ilişkin dağılım Tablo 1'de verilmektedir. Çalışmalar 


\section{Konferans Bildirilerindeki Temaların Dağıımı}

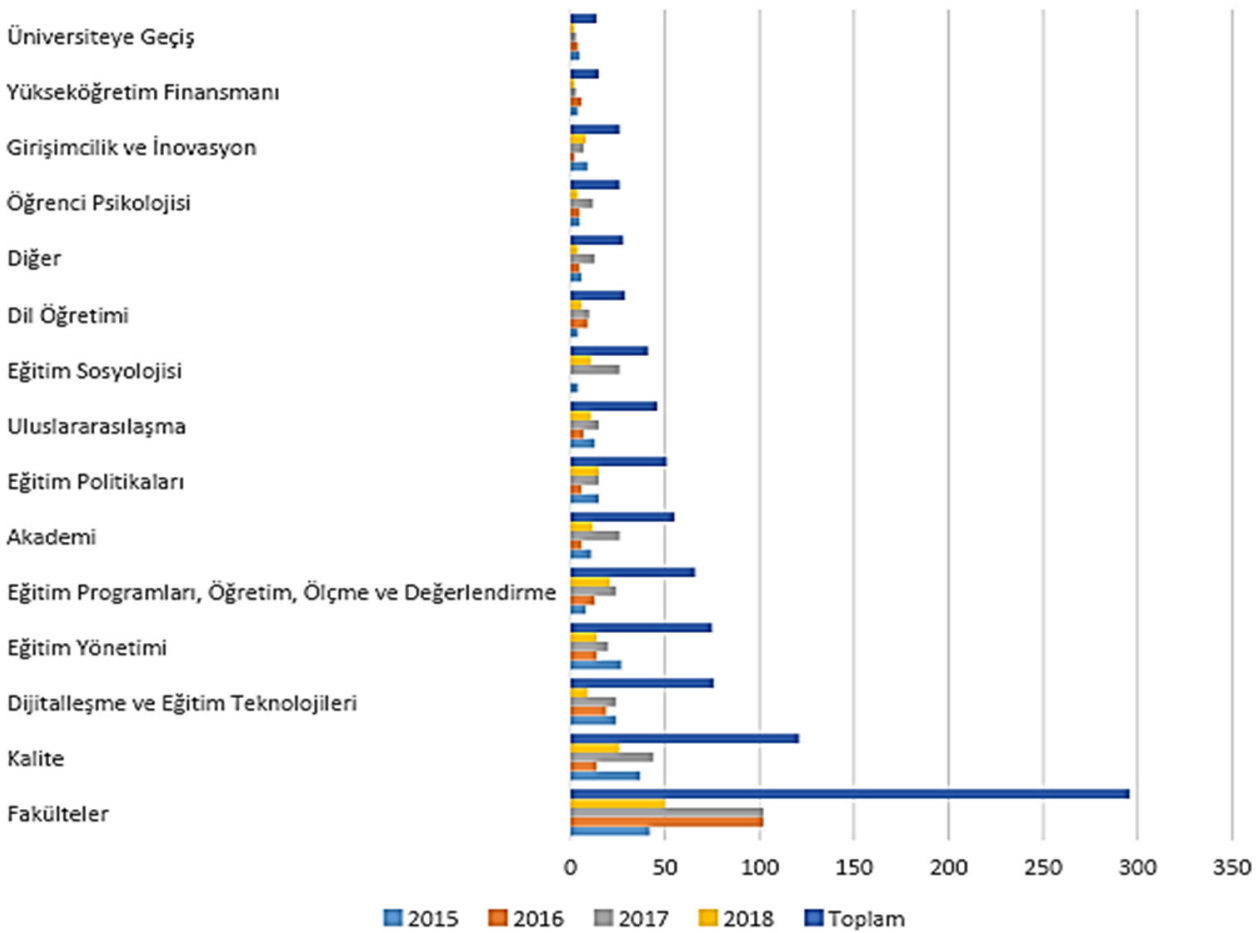

Şekil 2. Konferans Bildirilerindeki Temaların Dağılımları

Fakülteler Bazında Konferans Bildirilerindeki Temaların Dağııımı

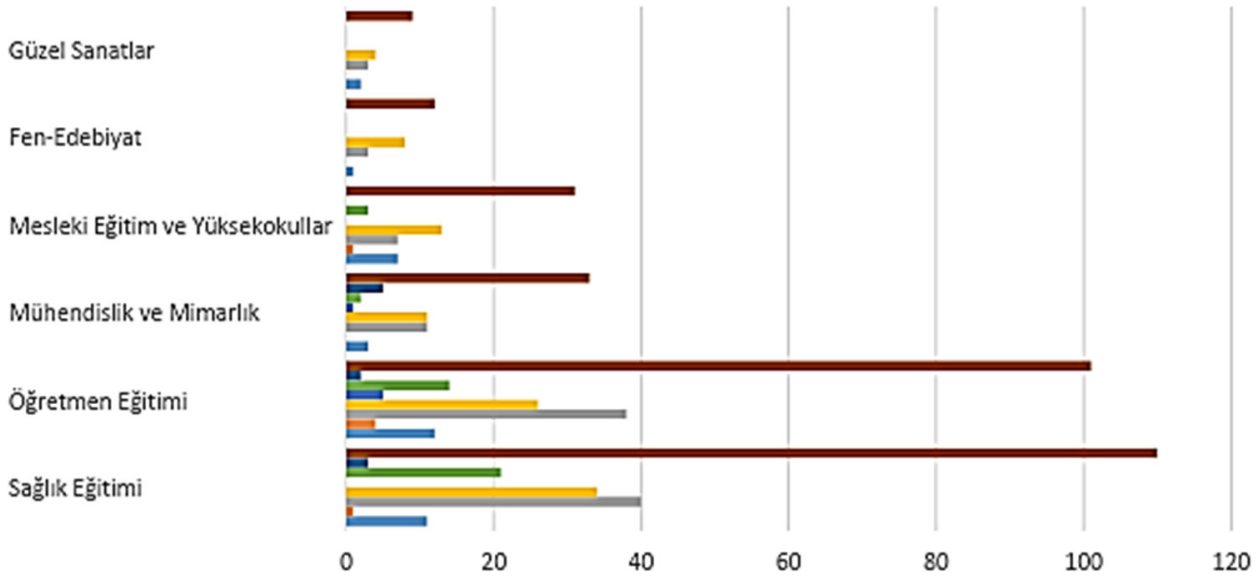

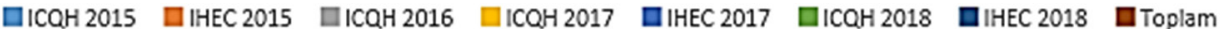

Şekil 3. Fakülteler Bazında Konferans Bildirilerindeki Temaların Dağılımı

Tablo 1. Konferans Bildirilerinin Araştırma Deseni ve Yöntemine Göre Dağılımı

\begin{tabular}{|c|c|c|c|}
\hline & & $f$ & $\%$ \\
\hline \multirow{4}{*}{ Araştırma Deseni } & Ampirik & 794 & 82.3 \\
\hline & Kavramsal & 106 & 11 \\
\hline & Belirtilmemiş & 65 & 6.7 \\
\hline & Toplam & 965 & 100 \\
\hline \multirow{6}{*}{ Araştırma Yöntemi } & Nitel & 358 & 45.1 \\
\hline & Nicel & 284 & 35.8 \\
\hline & Vaka çalışması & 114 & 14.4 \\
\hline & Karma desen & 32 & 4 \\
\hline & Belirtilmemiş & 6 & 0.7 \\
\hline & Toplam & 794 & 100 \\
\hline
\end{tabular}

incelendiğinde, çalışmaların büyük bir kısmının ampirik çalışmalardan (\%82.3) oluştuğu bulunmuștur. Bunun yanında, çalışmaların yüzde 11’i kavramsal tartışma içerirken yüzde 6.7'sindeki araştırma deseni ile ilgili bilgiler bildiri özeti ya da tam bildiri kitaplarından elde edilememiştir. Sunulan çalışmaların yarısına yakını (\%45.1) ise nitel araştırmalardan oluşmaktadır. Nitel araştırmaları, sırasıyla nicel (\%35.8), vaka çalışması (\%14.4) ve karma 
desende (\%4) çalıșmalar izlemiștir.

\section{Veri toplama araçları ve veri analizi:}

Bildirilerde sunulan ampirik çalışmaların dörtte biri doküman analizi çalışmalarıdır. Çalıșmaların \%20.5'inde ise ölçek aracılığıyla veri toplanmıștır. Veri analizlerine bakıldığında ise yine çalışmaların yarısından fazlasının betimsel analiz kullandığ sonra en çok kullanılan analiz yöntemleri ise çıkarımsal analiz (\%24.6) ve içerik analizidir (\%11.2).

\section{Katılımcılar ve örneklem büyüklükleri:}

Bildiriler örneklem temelinde incelendiğinde, sunulan bildirilerin \%41.8'inin herhangi bir örneklem içermeyen çalışmalar olduğu ortaya çıkmıştır. Tüm bildiriler içinde \%35.5 ile en çok örnekleme dâhil edilen grup üniversite öğrencileridir. Örneklem büyüklükleri incelendiğinde ise Tablo 2. Konferans Bildirilerinin Veri Toplama Araçları ve Veri Analizine Göre Dağılımı

\begin{tabular}{|c|c|c|c|}
\hline & & $f$ & $\%$ \\
\hline \multirow{11}{*}{ Veri Toplama Araçları } & Doküman Analizi & 199 & 25 \\
\hline & Ölçek & 163 & 20.5 \\
\hline & Anket & 106 & 13.3 \\
\hline & Mülakat & 92 & 11.6 \\
\hline & Alanyazın taraması & 83 & 10.4 \\
\hline & Veri & 35 & 4.4 \\
\hline & Karma & 31 & 4 \\
\hline & Odak grup & 11 & 1.4 \\
\hline & Gözlem & 7 & 1 \\
\hline & Belirtilmemiş & 67 & 8.4 \\
\hline & Toplam & 794 & 100 \\
\hline \multirow{7}{*}{ Veri Analizi } & Betimsel & 416 & 52.4 \\
\hline & Çıkarımsal & 195 & 24.6 \\
\hline & İçerik analizi & 89 & 11.2 \\
\hline & Karma & 8 & 1 \\
\hline & Diğer & 12 & 1.5 \\
\hline & Belirtilmemiş & 74 & 9.3 \\
\hline & Toplam & 794 & 100 \\
\hline
\end{tabular}

Tablo 3. Konferans Bildirilerinin Örneklem ve Örneklem Büyüklüğüne Göre Dağılımı

\begin{tabular}{|c|c|c|c|}
\hline & & $f$ & $\%$ \\
\hline \multirow{8}{*}{ Örneklem } & Öğrenciler & 282 & 35.5 \\
\hline & Akademisyenler & 63 & 8 \\
\hline & Birden çok örneklem & 30 & 3.8 \\
\hline & Yöneticiler & 15 & 2 \\
\hline & Diğer & 26 & 3.2 \\
\hline & Belirtilmemiş & 46 & 5.7 \\
\hline & Katılımcı bulunmayan & 332 & 41.8 \\
\hline & Toplam & 794 & 100 \\
\hline \multirow{8}{*}{ Örneklem Büyüklüğü } & $1-50$ arası & 88 & 11.1 \\
\hline & $50-100$ arası & 44 & 5.5 \\
\hline & $100-500$ arası & 136 & 17.1 \\
\hline & $500-1000$ arası & 31 & 4 \\
\hline & 1000 ve üzeri & 16 & 2 \\
\hline & Katılımcı bulunmayan & 332 & 41.8 \\
\hline & Belirtilmemiş & 147 & 18.5 \\
\hline & Toplam & 794 & 100 \\
\hline
\end{tabular}

tüm bildiriler bazında en çok 100-500 arası (\%17.1) ve 1-50 (\%11.1) arası katılımcı sayısına sahip bildirileri olduğu görünmektedir.

\subsection{Basılı yayınlara ilişkin bulgular}

Çalışmada incelenen makaleler 3 dergiden derlenmiştir. Bunlar Yükseköğretim Dergisi, Yükseköğretim ve Bilim Dergisi ve Üniversite Araştırmaları Dergisi'dir. Belirlenen dergilerde 2015-2018 yılları arasında basılan makaleler incelendiğinde toplamda 290 makalenin olduğu saptanmıştır. Bu çalışmalar arasından 2 makale, doğrudan yükseköğretim ile ilişkili olmadığı gerekçesiyle veri setinden çıkarılmıştır. Bu sebeple, analizlerde 288 çalışmaya ilişkin sonuçlar sunulmuştur.

\subsubsection{Basılı yayınlara ilişkin temalar}

Dergilerdeki makaleler incelendiğinde, çalışmaların çoğunun yine lisans programları üzerine olduğu bulunmuştur. Bu çalışmalar dışında üzerine en çok çalışılmış olan tema, akademi, lisansüstü eğitim ve etik gibi alt temaları bulunan "akademi" teması olmuştur. Bu temaları, eğitim (örgüt) yönetimi, uluslararasılaşma, yükseköğretim politikaları ve dijitalleşme ve eğitim teknolojileri izlemiştir.

Dergilerde basılmış olan makalelerde en sık karşılaşılan belirli lisans programlarının mevcut durumu ve iyileştirilmesine yönelik olan çalışmalar, fakülteler bazında değerlendirildiğinde, bu çalışmaların en çok öğretmen eğitimi ve sonrasında da sağlık eğitimi üzerine olduğu ortaya çıkarılmıştır. Üzerine en az çalışma olan alanlar ise güzel sanatlar ve fen-edebiyat fakültelerindeki lisans programları olmuştur.

\subsubsection{Basılı yayınlara ilişkin çalışma yöntemleri Araștırma deseni ve yöntemi:}

Dergilerdeki makalelerin araştırma deseni ve yöntemleri incelendiğinde, çalışmalarının çok büyük bir kısmının ampirik çalışmalar (\%95.8) olduğu ortaya çıkmıştır. Dergilerdeki ampirik çalışmalar araştırma yöntemi bazında incelendiğinde ise çalışmaların \%57.2'sinin nitel ve \%38.8'inin nicel çalışmalar olduğu bulunmuştur.

Tablo 4. Dergilerdeki Makalelerin Araştırma Deseni ve Yöntemine Göre Dağılımı

\begin{tabular}{|l|l|c|c|}
\hline & & $f$ & $\%$ \\
\hline \multirow{3}{*}{ Araştırma Deseni } & Ampirik & 276 & 95.8 \\
\cline { 2 - 4 } & Kavramsal & 12 & 4.2 \\
\cline { 2 - 4 } & Toplam & 288 & 100 \\
\hline \multirow{4}{*}{ Araştırma Yöntemi } & & & \\
\hline & Nitel & 158 & 57.2 \\
\cline { 2 - 4 } & Nicel & 107 & 38.8 \\
\cline { 2 - 4 } & Karma desen & 8 & 2.9 \\
\cline { 2 - 4 } & Vaka çalışması & 3 & 1.1 \\
\cline { 2 - 4 } & Toplam & 276 & 100 \\
\hline
\end{tabular}

Veri toplama araçları ve veri analizi:

Makalelerdeki ampirik çalışmalardaki veriler incelendiğinde, en çok kullanılan veri toplama araçlarının ölçek (\%28.3) ve doküman analizi (\%19.6) olduğu belirlenmiştir. Veri analizi bazında incelendiğinde ise çalışmaların ço- 
Dergilerdeki Temaların Dağılımı

Üniversiteye Geçiş

Girişimcilik ve Inovasyon

Yükseköğretim Finansmanı

Dil Öğretimi

Kalite

Öğrenci Psikolojisi

Eğitim Sosyolojisi

Diğer

Eğitim Programları, Öğretim, Ölçme ve Değerlendirme

Dijitalleşme ve Eğitim Teknolojileri

Eğitim Politikaları

Uluslararasılaşma

Eğitim Yönetimi

Akademi

Fakülteler

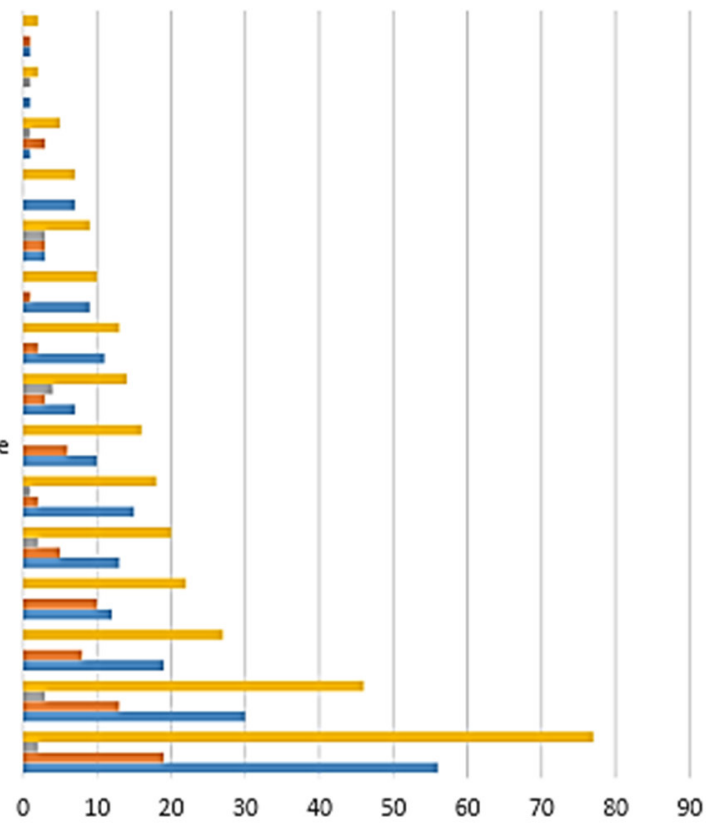

口Yükseköğretim ve Bilim घYükseköğretim घÜniversite Araştırmaları घToplam

Şekil 4. Dergilerdeki Makalelerin Temalara Göre Dağılımı

\section{Fakülteler Bazında Dergilerdeki Temaların Dağılımı}

Güzel Sanatlar

Fen-Edebiyat

Mühendislik ve Mimarlık

Mesleki Eğitim ve Yüksekokullar

Sağlık Eğitimi

Öğretmen Eğitimi

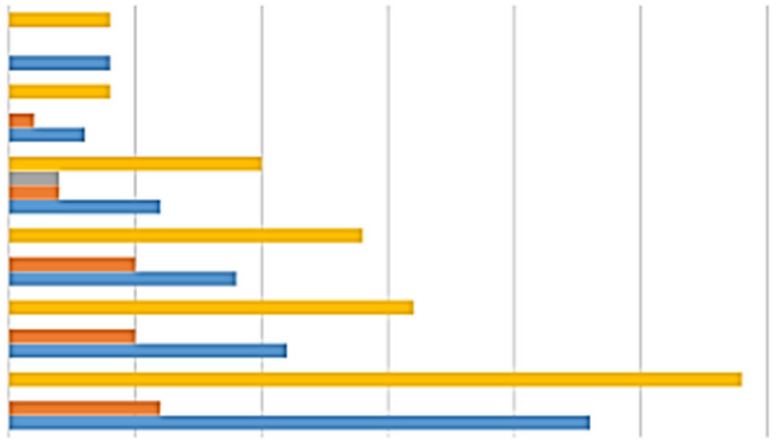

$10 \quad 15 \quad 20$

$25 \quad 30$

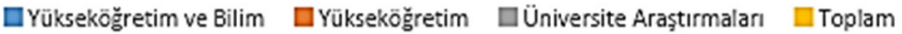

Şekil 5. Fakülteler Bazında Dergilerdeki Temaların Dağılımı

Tablo 5. Dergilerdeki Makalelerin Veri Toplama Araçları ve Veri Analizine Göre Dağılımı

\begin{tabular}{|l|l|c|c|}
\hline & & $f$ & $\%$ \\
\hline \multirow{5}{*}{ Veri Toplama Araçları } & Ölçek & 78 & 28.3 \\
\cline { 2 - 4 } & Doküman analizi & 54 & 19.6 \\
\cline { 2 - 4 } & Mülakat & 49 & 17.7 \\
\cline { 2 - 4 } & Veri & 32 & 11.6 \\
\cline { 2 - 4 } & Anket & 29 & 10.5 \\
\hline & Alanyazın taraması & 22 & 8 \\
\hline & Karma & 12 & 4.3 \\
\hline & Toplam & 276 & 100 \\
\hline \multirow{5}{*}{ Veri Analizi } & & 132 & 47.8 \\
\hline & Betimsel & 87 & 31.5 \\
\hline & Çıkarımsal & 50 & 18.1 \\
\hline & İçerik analizi & 7 & 2.6 \\
\hline & Karma & 276 & 100 \\
\hline & Toplam & & \\
\hline
\end{tabular}

Tablo 6. Dergilerdeki Makalelerin Örneklem ve Örneklem Büyüklüğüne Göre Dağılımı

\begin{tabular}{|c|c|c|c|}
\hline & & $f$ & $\%$ \\
\hline \multirow{7}{*}{ Örneklem } & Öğrenciler & 96 & 34.8 \\
\hline & Akademisyenler & 44 & 15.9 \\
\hline & Birden çok örneklem & 16 & 5.8 \\
\hline & Öğretmenler & 5 & 1.8 \\
\hline & Diğer & 7 & 2.5 \\
\hline & Katılımcı bulunmayan & 108 & 39.2 \\
\hline & Toplam & 276 & 100 \\
\hline \multirow{8}{*}{ Örneklem Büyüklüğü } & $1-50$ arası & 60 & 21.7 \\
\hline & $50-100$ arası & 13 & 4.7 \\
\hline & $100-500$ arası & 70 & 25.4 \\
\hline & $500-1000$ arası & 16 & 5.8 \\
\hline & 1000 ve üzeri & 6 & 2.2 \\
\hline & Katılımcı bulunmayan & 108 & 39.1 \\
\hline & Belirtilmemiş & 3 & 1.1 \\
\hline & Toplam & 276 & 100 \\
\hline
\end{tabular}


ğunun betimsel analiz (\%47.8) yoluyla verileri incelediği ortaya çıkmıştır.

\section{Katılımcılar ve örneklem büyüklükleri:}

Makalelerdeki çalışmalar örneklem bazında analiz edildiğinde, çalışmaların çoğunun, örnekleminin öğrencilerden (\%34.8) ve akademisyenlerden (\%15.9) oluștuğu ortaya çıkmıştır. Örneklem büyüklükleri incelendiğinde ise çalışmalarda en çok 100-500 arası (\%25.4) ve 1-50 (\%21.7) arası katılımcı sayısının dâhil edildiği görülmüştür.

\section{TARTIŞMA}

Bu çalışmada, 2015-2018 yılları arasında IHEC ve ICQH konferanslarında toplam 1.118 bildiri ve Yükseköğretim Dergisi, Yükseköğretim ve Bilim Dergisi ve Üniversite Araştırmaları Dergisi olmak üzere toplam 288 makale içerik analizi yöntemiyle incelenmiștir. Çalışmalardaki temel bulgular, aşağıda tema ve yöntem olmak üzere iki ana başlıkta tartışılmaktadır.

\subsection{Tema}

Çalışmanın en çarpıcı bulgularından biri, hem konferans bildirilerinde hem de dergi makalelerinde en çok çalışılan konunun lisans programları, bu programların değerlendirilmesi ve geliştirilmesine yönelik çalışmalar olduğudur. Her iki bağlamda da, fakülteler bazında en çok sağlık ve öğretmen eğitimi konuları yoğun olarak çalışılmıştır. Bu bulgu, çalışmaların yükseköğretimin makro düzeyinden ziyade mikro düzeyindeki uygulama ve politikalarına yönelik olduğunu göstermektedir. Nitekim, Gök ve Gümüş (2015) de, Türkiye'de yükseköğretim üzerine yapılan akademik çalışmaların alanın gelişmesi ve politikalara yön verilmesi açısından yetersiz olduğunu belirtmiştir. Bu doğrultuda, Gür ve Özoğlu (2015) da kalite, rekabet ve hesap verebilirlik gibi daha çok makro politikalara yönelik çalışmaların sayısının artması gerektiğini savunmuştur.

Bir başka çarpıcı bulgu da, literatürde belirtildiği üzere, Türkiye yükseköğretiminde politika yapıcıları düzeyinde son yıllarda öne çıkan kalite ve dijitalleşme temalarının, konferans çalışmalarında ilk sıralarda yer aldığı görülürken dergi makalelerinde alt sıralarda yer aldığıdır. Her iki konunun da yükseköğretim alanında görece yeni tartışllan konular olması, bu gibi güncel ve yeni kavramlara yönelik uygulamaların kolayca yapılamadığı, ve dolayısıyla konferanslarda bildiri kapsamında çalışmaların henüz yayına dönüşmemiş olduğu varsayılmaktadır. Bu sebeple, bu konulardaki yayın sayılarının ileride artacağı öngörülmektedir.

Tema bağlamında bir diğer göze çarpan konu da, hem konferanslarda hem de yayınlarda en az çalışılan konuların, ortak olarak, üniversiteye giriş, yükseköğretim finansmanı ile girişimcilik ve inovasyon konuları olduğudur. Üniversiteye giriş konusunun az çalışılması, yükseköğretim kurumlarının, program saylarının ve kontenjanlarının son yıllarda katlanarak artmasıyla yükseköğretime erişimin alanda temel bir sorunsal olmaktan çıktı mı sorusunu akla getirebilir. Yükseköğretim finansmanının az çalışılmasının temelinde yatan sebebin ise, özellikle devlet üniversitelerinde, ki yükseköğretimin çok büyük bir kısmını olușturmaktadır, finansal özerkliklerinin kısıtlı olması ve bu konunun yükseköğretimin bir çıkmaz sokağı olduğu düşüncesinden kaynaklanabilir. Bu durum, üniversitelerin mali özerkliklerini tartışan çeşitli çalışmalarda da dile getirilmiştir (Erdem, 2013b; Çelik \& Gür, 2014). Ortaya çıkan bir başka düşünce de, yükseköğretim finansmanı çalışan ekonomistlerin var olup olmadığı ya da varsa da kendilerini yükseköğretim alanına ne kadar yakın ve ait hissedip hissetmediğidir.

Benzer şekilde, girişimcilik ve inovasyon konularının her ne kadar dünya gündeminde öne çıkan konulardan biri de olsa oldukça az çalışılması, yine bu konuların mühendislik ve iktisadi idari bilimlerin konusu kapsamına girdiğinin düşünüldüğü olasılığıdır. Nitekim, yükseköğretim alanında girişimcilik ve inovasyon konuları üzerine yayınları bulunan yazarların, yine mühendislik ve iktisadi idari bilimlerden olması bu olasılı̆̆ı güçlendirmektedir (Sakınç \& Bursalığlu, 2013; Öztemel, 2013; Odabaşı, 2006). Bu bağlamda, Yükseköğretim Çalışmaları bilim alanı, Türkiye'de her ne kadar Sosyal, Beșeri ve İdari Bilimler temel alanının altında açılmış olsa da henüz o fakültelerde bu alanda bir programın açılmamış olması, bu iddiayı güçlendirmekte ve Eğitim fakülteleri bilim insanlarının yükseköğretim çalışmalarını daha çok sahiplendiği ve alandaki çalışmaları yönlendirdiği kanısını desteklemektedir. Bunun yanında, bulgularımızda görüldüğü üzere özellikle öğretmen eğitiminin çok çalışılan temalardan biri olması da bu iddiamızla örtüşmektedir.

Yükseköğretim politikaları bağlamında düşünüldüğünde, konferanslarda uluslararasılaşma konusunun az çalışılması ve kalite ve dijitalleşmenin dergilerde henüz yer almaması, veri-temelli politikaların oluşturulması açısından doldurulması gereken bir boşluk olarak düşünülebilir. Genişleme ile birlikte yükseköğretim gelişmelerinin politika oluşumu kapsamında hızla arttığı bir dönemde, özellikle 2015-2018 yılları arasında oluşturulan makro politikaların ve yapılan bilimsel çalışmaların birbirini ne kadar beslediği ve birbirinden ne kadar beslendiği bir sorunsal olarak belirmektedir. Bu bağlamda, özellikle 20152018 yıllarının önemli politika oluşumları kapsamında, misyon farklılaşması ve ihtisaslaşma, meslek yüksekokullarının niteliği, ve doktora eğitimi konularında, özellikle temsil gücü yüksek bilimsel verilerin fazlalaştırılıp yaygınlaştırılması için araştırmacılara; lisans programları ve özellikle öğretmen eğitimi ve sağlık eğitimi konularında elde edilmiş olan verilerin derlenip analiz ve sentez edilmesi yolu ile, var olan ilgili politikaların geliştirilmesi için de politika yapıcılarına önemli görevler düştüğünün altını çizmek önemlidir.

\subsection{Yöntem}

Çalışmalar yöntem açısından düşünüldüğünde, kavramsal çalışmalara kıyasla ampirik çalışmaların çok daha ön 
planda olduğu ve bu ampirik çalışmaların içinde de nitel araştırma yaklaşımlarının nicel araştırma yaklaşımlarına kıyasla görece daha sık kullanıldığı ortaya çıkmıştır. Veri toplama araçları göz önünde bulundurulduğunda, çoğunlukla doküman analizi ve ölçekler yoluyla veri toplandığ anlaşılmaktadır. Ayrıca, bu verilerin büyük bir kısmı, betimsel analiz yapılarak incelenmiştir. Bunun yanında, verilerin ağırlıklı olarak yükseköğretim öğrencileri grubundan toplanıldığı ve örneklem büyüklerinin temsil etme güçlerinin düşük olduğu saptanmıştır. Bu sonuçlar, alandaki çalışmaların özgün model veya kuram geliştirmekten ziyade var olan model ve kuramların küçük ölçekli gruplarla irdelendiğine işaret etmektedir. Bu durum, bu alanda çalışan akademisyenlerin daha çok atama yükseltme kriterlerini sağlamaya ve akademik teşvikten faydalanmaya odaklandıklarını ve bu şartları sağlamak amacıyla kısa sürede tamamlanabilecek çalışmalara ağırlık verdiklerini düşündürmektedir. Nitekim, yükseköğretim alanında yapılan çeşitli çalışmalarda da bu sorunun altı çizilmiştir (Turhan \& Erol, 2017; Ültay \& Ültay, 2018; Yokuş, Ayçiçek \& Kanadlı, 2018). Örneğin, akademik teşvik ödeneği uygulaması ile ilgili yapılan bir çalışmada, akademisyenlerin teşvik uygulamasının etkililiği ile ilgili farklı görüşleri bulunsa da öne çıkan temalardan birinin uygulamanın nitelikten çok niceliği önceliklendirdiğidir (Şahin, Tabak \& Tabak, 2017). Benzer şekilde, öğretim üyelerinin akademik yükseltme ve atama süreçleriyle ilgili görüşlerinin araştırıldığı bir diğer çalışmada da, yapılan yayın ve bildirilerde asıl motive edici unsurun nitelikle çalışmalardan ziyade doçentlik kriterlerini sağlayacak sayıda araştırma yapabilmek olduğu ortaya çıkmıştır (Demir, Göloğlu Demir \& Özdemir, 2017).

\subsection{Sınırlılıklar}

Her çalışmada olduğu gibi bu çalışmanın da bazı sınırlılıkları bulunmaktadır. Bu çalışmadaki en önemli sınırlılık, sadece yükseköğretim odaklı dergiler ve konferansların veriye dâhil edilmesidir. Fakat bilindiği üzere, temel odağ yükseköğretim olmayan eğitim ve sosyal bilimler alanındaki pek çok kongre ve dergilerde yükseköğretim ile ilgili araştırmalar bulunmaktadır. Türkiye'de çıkarılan dergi ve düzenlenen kongrelerin tümünün incelenmesi mümkün olmadığından, bu çalışmadaki veriler, yükseköğretim odaklı konferans ve dergiler ile sınırlı kalmaktadır. Çalışmadaki bir diğer sınırlılık da, analize tabi tutulan çalışmaların Türkiye'deki dergi ve konferanslar kapsamında olmasıdır.

\section{SONUÇ VE ÖNERILER}

Yükseköğretim, hem istihdama açılan bir kapı niteliğinde ekonomik gelişime katkı vermesi bakımından hem de kişinin mesleki ve akademik gelişiminin yanı sıra psikolojik, sosyal ve kültürel gelişimlerine katkı vermesi bakımından toplumsal gelişimde oldukça önemli bir yere sahiptir. Bu açıdan düşünüldüğünde, bu çalışmanın bulguları kapsamında, yükseköğretim çalışmaları alanında yapılan bilim- sel çalışmaların öneminin, sistemin gelişmesi ve ilerlemesi açısından hayati olduğu bir gerçektir. 2015-2018 yılları arasında Türk akademisinde yapılmış olan çalışmaların, yeni oluşan bir alanı tanımlamaya ve konumlandırmaya yönelik olması son derece anlaşılabilir bir durumdur. Ancak, bu noktadan itibaren, belki de artık özellikle yöntemleri bakımından etki alanı daha geniş sonuçlara ulaşılabilmesi için büyük ölçekli verilere ihtiyaç bulunmaktadır. Bu açıdan Erdoğan (2014), Türkiye yükseköğretiminin öncelikli gündemini incelediği çalışmasında, yükseköğretime ilişkin temel verilerin kamuoyu ile paylaşılmasının, alandaki akademik araştırmalar için önemli olacağının altını çizmiştir. Benzer şekilde Tekneci (2016) de, Türkiye yükseköğretiminin güncel durumu, alandaki beklenti ve eğitimleri anlamak adına YÖK ve diğer kamu kuruluşlarının uluslararası karşılaştırma çalışmalarında da kullanabilecek nitelikte verilerin oluşturmasının önemine dikkat çekmiştir.

Bir diğer husus da, yükseköğretimin kapsamının geniş ve paydaşlarının oldukça fazla olduğudur. Bu bağlamda, sadece öğrencilerden ve akademik personelden oluşan çalışmaların yanı sıra idari personel, iş ve kamu dünyası çalışanları, ve bakanlıklar düzeyinde ilgili kişilerin çalışmalara dâhil edilmesi, hem veri çeşitliliğine imkân tanıyacak hem de çalışma sonuçlarını daha kapsamlı hale getirecektir.

Uzun soluklu çalışmalardan elde edilecek temsili verilerin toplanması ve eleştirel analizlerin yapılması, veri temelli makro politikalara yol vermesi ve gerek yönetişim gerekse finansal açıdan sürdürülebilir bir yükseköğretim için son derece gereklidir.

Bu çalışmanın sonuçları ışığında, akademisyenlere, konferans düzenleyicilerine, dergi editörlerine, üniversite idarecilerine ve politika yapıcılarına bir takım öneriler geliştirilmiştir:

Araştırmacıların, temsil gücü yüksek örneklemler ile yapılan ampirik çalışmaların yanı sıra özgün model ve kuram geliştirmeye yönelik uzun soluklu ve büyük ölçekli çalışmalara yönlenmeleri; akademik niteliği yüksek, dünya çapında alanyazına öncülük edebilecek araştırma projeleri geliştirmeleri ve bunların bulgularının bulundukları bölgeye ve topluma katkı sunmasını sağlamaları; ulusal veya uluslararası seviyelerde hem disipliner hem de disiplinlerarası işbirlikleri kurmaları, veri tabanları oluşturmaları ve yaygınlaştırmaları; öğrencilerini bu alan ile ilgili daha da nitelikli araştırma ve lisansüstü tez çalışmaları yapmaya ve yaygınlaştırmaya teşvik etmeleri;

Konferans düzenleyicilerinin, farklı disiplinlerde konferanslarını duyurmaya ve alanı tanıtmaya yönelik çalışmalar yapması ve farklı disiplinlerde çalışan bilim insanlarını bu alana katkı vermeye teşvik etmesi ve bu şekilde disiplinlerarası bir akademi topluluğunun oluşturulmasına yol açması;

Dergi editörlerinin de disiplinlerarası bilim insanlarından 
olușması ve farklı disiplinlerden bilimsel makale bașvurularının alınabilmesi için dergileri farklı disiplinlerde duyurmaya ve tanıtmaya yönelik çalışmalar yapması;

Yükseköğretim kurumları idarecilerinin, özellikle akademisyenlerin yetişmesine olanak sağlayacak şekilde lisansüstü seviyede yükseköğretim çalışmaları programlarının açılmasını teşvik etmesi ve üniversitelerde yükseköğretim çalısmaları alanının ve mevcut merkezlerin güçlendirilmesine yönelik girişimlere öncülük etmeleri;

Politika yapıcılarının, yükseköğretim çalışmalarına öncelikli çalıșma alanları kategorisinde yer vermesi, araştırmacılar ile daha sıkı işbirlikleri kurması, politikaların var olan araştırmalardan beslenmesi ve aynı zamanda araştırmaları da beslemesi için artırılması; tavsiye edilmektedir. $\mathrm{Bu}$ önerilerin kısa, orta ve uzun vade stratejik planlama çalışmaları ışığında nitelikli bir şekilde hayata geçirilmesi, hem bir bilim alanı olarak yükseköğretim çalışmalarını yaygınlaştıracak ve merkeze taşıyacak hem de Türkiye yükseköğretiminin niteliğini artırıp güçlendirecektir.

\section{KAYNAKÇA}

Akbulut Yıldırmış, M. \& Seggie, F. N. (2018). Yükseköğretim çalışmalarının akademik bir alan olarak gelişimi: Uluslararası ve ulusal düzeyde alanyazın incelemesi. Yükseköğretim Dergisi, 8(3), 357-367.

Altbach, P. G. (2014). Knowledge for the contemporary university: Higher education as a field of study and training. L. E. Rumbley, P. G. Altbach, D. A. Stanfield, Y. Shimmi, A. de Gayardon, and R. Chan (Ed.), Higher education: A worldwide inventory of research centers, academic programs, and journals and publications (3. bs.) (ss. 11-21). Bonn: Lemmens Media.

Barnett, R. (1990). The idea of higher education. Buckingham: SRHE / Open University Press.

Brennan, J., and Teichler, U. (2008). The future of higher education and of higher education research. Higher Education, $56,259-264$.

Choi, B. C., vd. (2005). Can scientists and policy makers work together?. Journal of Epidemiology \& Community Health, 59(8), 632-637.

Çelik, Z., \& Gür, B. S. (2014). Yükseköğretim sistemlerinin yönetimi ve özerkliği: Küresel eğilimler ve Türkiye örneği. Yükseköğretim ve Bilim Dergisi, 4(1), 18-27.

Demir, E., Göloğlu Demir, C., \& Özdemir, M. Ç. (2017). Akademik Yükseltme ve Atama Sürecine Yönelik Öğretim Üyesi Görüşleri. Yükseköğretim ve Bilim Dergisi, 7(1).

Erdem, A. R. (2013a). Bilgi toplumunda üniversitenin değişen rolleri ve görevleri. Yükseköğretim Dergisi, 3(2), 109-120.

Erdem, A. R. (2013b). Üniversite özerkliği: mali, akademik ve yönetsel açıdan yaklaşım. Yükseköğretim ve Bilim Dergisi, 3(2).

Erdoğan, A. (2014). Türkiye'de yükseköğretimin gündemi için politika önerisi, Yükseköğretim ve Bilim Dergisi, 4(1), 1-17.

Erdoğan, A. (Ed.). (2010). Yükseköğretimde yeniden yapılanma: 66 soruda Bologna süreci uygulamaları. Ankara: Yükseköğretim Kurulu.
Ferlie, E., Musselin, C., \& Andresani, G. (2008). The steering of higher education systems: A public management perspective. Higher education, 56(3), 325.

Fulton, O. (1992). Higher education studies. In B. R. Clark, and G. Neave (Eds.), The encyclopedia of higher education (Vol. 3, pp. 1810-1820). New York, NY: Pergamon Press.

Gök, E., \& Gümüş, S. (2015). Akademik bir alan olarak yükseköğretim yönetimi. A. Aypay (Ed.), Türkiye'de yükseköğretim: Alanı, kapsamı ve politikaları (ss. 3-26), Ankara: Pegem Akademi.

Günay, D. (2011). Türk yükseköğretiminin yeniden yapılandırılması bağlamında sorunlar, eğilimler, ilkeler ve öneriler-I. Yükseköğretim ve Bilim Dergisi, 1(3).

Günay, D. \& Günay, A. (2017). Türkiye'de yükseköğretimin tarihsel geliflimi ve mevcut durumu. Yükseköğretim Dergisi, 7(3), 156-178.

Gündoğdu, K., Çelik, B., Yanar, B. H., Yolcu, O., \& Ceylan, V. K. (2016). Türkiye'de yükseköğretimde program geliştirme bağlamında uluslararasılaşma. Atatürk Üniversitesi Kazım Karabekir Eğitim Fakültesi Dergisi, 33, 35-48.

Gür, B. S., \& Özoğlu, M. (2015). Türkiye'de yükseköğretim politikaları: erişim, kalite ve yönetim. A. Gümüş (Ed.), Türkiye'de Eğitim Politikaları (ss. 299-321). Ankara: Nobel.

Gürüz, K. (2003). Dünyada ve Türkiyéde yükseköğretim: Tarihçe ve bugünkü sevk ve idare sistemleri. Ankara: ÖSYM YayınlarI.

https://eacea.ec.europa.eu/sites/2007-2013/lifelong-learning-programme/ects-and-diploma-supplement-labels_ en, erişim 1.12.2019.

https://istatistik.yok.gov.tr, erişim 1.12.2019.

https://www.yok.gov.tr/Sayfalar/Haberler/agri-dijital-donusum-tanitim-toplantisi.aspx, erişim 1.12.2019.

Karakütük, K., \& Özdemir, Y. (2011). Bilim insanı yetiştirme projesi (BiYEP) ve öğretim üyesi yetiştirme programı́nın (ÖYP) değerlendirilmesi. Eğitim ve Bilim, 36(161).

Kayıkcı, S. (2018). Yönetişimin kamu kurumlarında uygulanabilirliği: yükseköğretim kurulu başkanlığı örneği. Ombudsman Akademik, (1), 163-181.

Kızıltepe, Z. (2017). İçerik analizi. F. N. Seggie ve Y. Bayyurt (Ed.), Nitel araştırma: Yöntem, teknik, analiz ve yaklaşımları (ss. 689-713). Ankara: Anı Yayıncılık.

Lewis, J. (2003). Design issues. J. Ritchie ve J. Lewis (Ed.), Qualitative research practice: A Guide for social science students and researchers (ss. 47-76). London, UK: SAGE Publications.

Odabaşı, Y. (2006). Değişimin ve dönüşümün aracı olarak girişimci üniversite. Girişimcilik ve Kalkınma Dergisi, 11(1), 87104.

Okumuş, K. \& Yurdakal, İ.H. (2017). Akademisyenlerin akademik teşviğe ilişkin görüş ve düşünceleri. Journal of Academic Social Science Studies, 58, 145-156.

Öztemel, E. (2013). Yükseköğretim kurumlarında araştırma ve inovasyon kültürünün oluşturulması. Yükseköğretim Dergisi, 3(1), 22-29.

Sakinç, S. \& Bursalioğlu, S. A. (2012). Yükseköğretimde küresel bir değişim: Girişimci üniversite modeli. Yükseköğretim ve Bilim Dergisi, 2(2). 
Saraç, Y. (2019). Araştırma ve Aday Araştırma Üniversiteleri 2017 ve 2018 Yılları Performans İleme ve Değerlendirme Sonuçları Toplantısı. Yükseköğretim Kurulu.

Şahin, F., Tabak, B. Y., \& Tabak, H. (2017). Motivasyon kuramları bağlamında akademik teşvik ödeneği uygulamasının değerlendirilmesi. Yükseköğretim ve Bilim Dergisi, 7(2), 403410.

Tekeli, İ. (2010). Tarihsel bağlamı içinde Türkiye'de yükseköğretimin ve yök'ün tarihi. Tarih Vakfı Yurt Yayınları.

Tekneci, P. D. (2016). Evolution of Turkish higher education system in the last decade. Yükssekögrretim ve Bilim Dergisi, 6(3), 277-287.

Tierney, W. G., \& Lechuga, V. M. (2005). Academic freedom in the 21st century. Thought \& Action, 21, 7-22.

Turan, H. (2019). Veriye dayalı karar verme. N. Cemaloğlu (Ed.), Veriye dayalı yönetim (ss. 1-20). Ankara: Pegem Akademi.

Turan, Ş. A., Dil, E., \& Sağır, P. M. (2019). Performans odaklı bir üniversitede akademisyenlerin çalışma deneyimleri. Yönetim Bilimleri Dergisi, 17(33), 59-84.

Turhan, M., \& Erol, Y. C. (2017). Akademisyenlerin akademik teşvik ödeneğine ilişkin görüşleri. Inonu University Journal of the Faculty of Education (INUJFE), 18(3).

UNESCO (2017). UNESCO Institute for Statistics. 2 Ağustos 2017 tarihinde http://uis.unesco.org/ adresinden erişildi.

UNESCO (2019). UNESCO Institute for Statistics. 11 Nisan 2019 tarihinde http://uis.unesco.org/ adresinden erişildi.

Usta, A. (2019). Evreleri ile bilimsel araştırma süreci ve raporlaştırılması. ASSAM Uluslararası Hakemli Dergi, 6(13), 85-101.

Ültay, E., \& Ültay, N. (2018). Akademik teşvik ödeneğinin bilimsel faaliyetlere etkisi hakkındaki akademisyen görüşleri. Yükseköğretim ve Bilim Dergisi, 8(1).

Winch, C., \& Clarke, L. (2003). Front-loaded vocational education versus lifelong learning. A critique of current UK government policy. Oxford Review of Education, 29(2), 239-252.

Wright, D. (2007). Progress in the development of higher education as a field of specialized study. D. Wright, and M. T. Miller (Eds.), Training Higher Education Policy Makers and Leaders: A Graduate Perspective (ss. 19-34). Charlotte, NC: Information Age.

Yin, R. K. (2011). Qualitative research from start to finish. New York, NY: The Guilford Press.

Yokuş, G., Ayçiçek, B., \& Kanadlı, S. (2018). Akademisyen görüşleri doğrultusunda yükseköğretimde performansa dayalı akademik teşvik sisteminin incelenmesi. Yükseköğretim Dergisi, 8(2), 140-149.

Yükseköğretim Kurulu. (2006). Türkiye'nin yükseköğretim stratejisi (taslak rapor). Ankara. 